\title{
E-SHOPS EVALUATION DURING COVID-19 LOCKDOWN USING E-S-QUAL AND AHP-TOPSIS
}

\author{
Xenia J. Mamakou and Konstantina - Porfyria Roumeliotou \\ Athens University of Economics and Business \\ 76 Patission Str. Athens, Greece
}

\begin{abstract}
This paper uses the E-S-QUAL model, analytic hierarchy process (AHP), and technique for order performance by similarity to ideal solution (TOPSIS) to evaluate e-commerce B2C websites among coffee-chain leaders in the Greek market. The research took place during the lockdown in Greece, due to COVID-19, which increased online sales. Our findings suggest that system availability and fulfillment are the two most important dimensions of the model, while credit card information protection and webpages that do not freeze during the ordering process are considered as the most crucial sub-dimensions. Our proposed 12-step approach can help web developers focus on the most important factors when designing e-shops, while companies can lead their efforts in improving service quality when offering their products and services to online customers. Moreover, the results of the evaluation process highlight the coffee-chain e-shop that could serve as a benchmark for best practices in online service quality.
\end{abstract}

\section{KEYWORDS}

E-commerce, Website Evaluation, E-S-QUAL, AHP, TOPSIS

\section{INTRODUCTION}

COVID-19 has changed the way people communicate, work, learn, travel, and behave during everyday life. Apart from the obvious health side-effects, business in many fields has decreased dangerously, causing company bankruptcies and loss of many jobs. In many cases, business and education can stay operational using available online technology. E-learning platforms help students in all educational levels continue the learning process, whereas online capabilities of corporate information systems and communication platforms assist professionals to continue their work from home. Recent studies (Contactpigeon, 2020, Eltrun, 2020) reveal that due to COVID-19 and the enforcement of lockdown in many countries, online shopping has increased, especially in the fields of consumer electronics and food \& drink.

Businesses are required to respond immediately to such market changes, to satisfy customers, and to diversify from the competition. To achieve these goals, companies need to deeply understand the online customer experience. This way, they can improve the placement of their products and services as well as their communication. Past experiences could affect current and future experiences. Such experiences include e-shop navigation, searching capabilities, pricing policy, and after-sales service. According to (Grewal and Roggeveen, 2020) even the way a product is delivered and packaged could have a significant impact on current and future consumer experience.

In this vein, our research focuses on e-shops evaluation during COVID-19 lockdown in Greece. Our goal is to weight and rank the elements that affect online service quality and then evaluate the e-commerce websites of the top coffee-chains in the Greek market. The rest of the paper is organized as follows. Section 2 presents a literature review of service quality and its implementation in related studies. Section 3 outlines the research methodology implemented in the paper. Section 4 presents the results of this study and Section 5 discusses the conclusions. 


\section{LITERATURE REVIEW}

Service quality has been a subject for research in many studies (Arcand et al., 2017, Suhartanto et al., 2019, Santos, 2003). Quality of services is one of the elements that build customer loyalty (Wirtz and Lovelock, 2016). Several instruments have been developed by researchers to measure service quality, with SERVQUAL (Parasuraman et al., 1988) to be one of the most known and widely used. The advent of the Internet and the spread of electronic services has created the need for different or modified instruments, to be able to measure electronic service quality. Such instruments include e-SQ (Zeithaml et al., 2000), which captures customers' interactions with a website, WebQual (Loiacono et al., 2002), based on 12 dimensions to measure website quality, SITEQUAL (Yoo and Donthu, 2001) and eTailQ (Wolfinbarger and Gilly, 2003) based on 4 dimensions. Criticism has been made to all these instruments, for either been used only to students, not capturing all aspects of the purchasing process, lacking internal consistency (Parasuraman et al., 2005), or focusing mainly on giving feedback to website designers (Zeithaml et al., 2002).

To overcome these limitations, Parasuraman et al. (Parasuraman et al., 2005) developed a four-dimension, 22 items instrument, called E-S-QUAL, that captures all phases of customers' interactions with a website. These dimensions include efficiency (eight items), system availability (four items), fulfillment (seven items), and privacy (three items). Efficiency refers to the ease and speed of accessing and using a website. System availability measures the technical functionality of the website. Fulfillment inspects the extent to which the website's promises about order delivery and item availability are fulfilled. Finally, privacy measures the degree to which a website is safe and protects customer information. Table 1 presents the dimensions and sub-dimensions of the E-S-QUAL model.

Table 1. Dimensions and sub-dimensions of E-S-QUAL model

\begin{tabular}{|c|c|}
\hline Dimensions & Sub-dimensions \\
\hline \multirow[t]{8}{*}{ Efficiency } & This site makes it easy to find what I need $\left(\mathrm{SD}_{11}\right)$ \\
\hline & It makes it easy to get anywhere on the site (SD12) \\
\hline & It enables me to complete a transaction quickly ( $\left.\mathrm{SD}_{13}\right)$ \\
\hline & Information at this site is well organized ( $\left.\mathrm{SD}_{14}\right)$ \\
\hline & It loads its pages fast $\left(\mathrm{SD}_{15}\right)$ \\
\hline & This site is simple to use ( $\left.\mathrm{SD}_{16}\right)$ \\
\hline & This site enables me to get on to it quickly $\left(\mathrm{SD}_{17}\right)$ \\
\hline & This site is well organized $\left(\mathrm{SD}_{18}\right)$ \\
\hline \multirow[t]{4}{*}{ System Availability } & This site is always available for business $\left(\mathrm{SD}_{21}\right)$ \\
\hline & This site launches and runs right away $\left(\mathrm{SD}_{22}\right)$ \\
\hline & This site does not crash $\left(\mathrm{SD}_{23}\right)$ \\
\hline & Pages at this site do not freeze after I enter my order information $\left(\mathrm{SD}_{24}\right)$ \\
\hline \multirow[t]{7}{*}{ Fulfillment } & It delivers orders when promised $\left(\mathrm{SD}_{31}\right)$ \\
\hline & This site makes items available for delivery within a suitable time frame $\left(\mathrm{SD}_{32}\right)$ \\
\hline & It quickly delivers what I order ( $\left.\mathrm{SD}_{33}\right)$ \\
\hline & It sends out the items ordered $\left(\mathrm{SD}_{34}\right)$ \\
\hline & It has in stock the items the company claims to have ( $\left.\mathrm{SD}_{35}\right)$ \\
\hline & It is truthful about its offerings ( $\left.\mathrm{SD}_{36}\right)$ \\
\hline & It makes accurate promises about the delivery of products $\left(\mathrm{SD}_{37}\right)$ \\
\hline \multirow[t]{3}{*}{ Privacy } & It protects information about my Web-shopping behavior $\left(\mathrm{SD}_{41}\right)$ \\
\hline & It does not share my personal information with other sites $\left(\mathrm{SD}_{42}\right)$ \\
\hline & This site protects information about my credit card $\left(\mathrm{SD}_{43}\right)$ \\
\hline
\end{tabular}

E-S-QUAL has been tested in many studies. Santouridis et al. (Santouridis et al., 2012) examined the applicability of E-S-QUAL and its factor structure in the context of e-commerce in Greece. Their findings confirmed the E-S-QUAL model and produced similar results to those of the initial research. Kandulapati and Bellamkonda (Kandulapati and Bellamkonda, 2014) measured the service quality of online shops using E-S-QUAL and validated the tool in an Indian context. Their study revealed that E-S-QUAL was valid for measuring service quality in the context of Indian online shopping. Ahmed et al. (Ahmed et al., 2020) employed E-S-QUAL to examine electronic banking service quality and customer satisfaction. Their finding confirmed an affirmative and potent impact of E-S-QUAL dimensions on customer's satisfaction. Dalbehera (Dalbehera, 2020) adopted the E-S-QUAL model to identify the criteria to assess the service quality of a University library 
website from the research scholars' viewpoints. The purpose of this study was to investigate the effects of E-S-QUAL dimensions that influence the digital library services on user's perceived value, e-service quality and e-loyalty. The findings revealed that the E-S-QUAL scale was a valid instrument for measuring e-service quality in the context of digital library services.

Website evaluation has been studied in the past. Masudin and Saputoro (Masudin and Saputro, 2016) evaluated B2C websites based on usability heuristics using fuzzy AHP \& hierarchical fuzzy TOPSIS. Their results revealed that security and privacy is the most important factor followed by trust, loading time, easy transaction, and e-payment support. Soleymaninejad et al. (Soleymaninejad et al., 2016) evaluated two main online travel agencies in the US market with TOPSIS using a six-factor scale. They found that visibility and findability and functionality and accessibility were the most important criteria in their study. Ostovare and Shahraki (Ostovare and Shahraki, 2019) evaluated the status of websites and e-services provided by five-star hotels. They determined the main criteria and subcriteria using fuzzy Delphi method and weighted them using the Shannon entropy method. PROMETHEE and GAIA methods were then implemented to rank and develop the visual aid of websites. Their results revealed that customer orientation was the most important criterion, followed by marketing, security, and technology. Kang (Kang et al., 2016) presented a new method for evaluating B2C e-commerce websites, with the integration of E-S-QUAL and fuzzy hierarchical TOPSIS. To illustrate the efficacy of the proposed approach, they selected to evaluate six widely used Korean B2C e-commerce websites that provide similar services.

\section{METHODOLOGY}

This paper is based on a multiple criteria decision making (MCDM) approach that combines more than one research methodology, to overcome the limitations of the use of a single technique. In this vein, our research is based on AHP and TOPSIS, a combined methodology used in many studies (Zaidan et al., 2015, Hanine et al., 2016, Sharma and Joshi, 2019).

An online questionnaire was developed and used to capture experts' opinions regarding the importance of the dimensions related to website evaluation. The questionnaire consisted of three parts. The first part was asking experts to make pairwise comparison judgments between the 4 main dimensions and the 22 sub-dimensions of the E-S-QUAL model. The results of this analysis with AHP are used to evaluate the relative importance of the factors that influence users' decisions on choosing a website to make online purchases. The second part of the questionnaire was urging the experts to visit the websites under evaluation and to provide an answer for each of the model's sub-dimensions on a 9-level Likert scale. Their answers are analyzed using TOPSIS to provide a ranking of the evaluated websites. The final part of the questionnaire consisted of demographic questions.

Three B2C websites of Greek coffee-chains that rank among Europe's top 15 brands, according to FoodService Europe \& Middle East magazine (Foodservice, 2019) were chosen to be evaluated. The research took place in the period of lockdown due to COVID-19, during April and May 2020. 25 experts agreed to take part in the research. They were all advanced web users, familiar with online purchases, professionals in website development, and/or UX design. Similar researches use sample sizes ranging from just 3 (Kang et al., 2016), to 27 (Ocampo et al., 2019). Thus, our sample size is considered acceptable for the proposed methodology.

Our methodology was based on the following steps, which are in accordance with the research of Ocampo et al. (Ocampo et al., 2019):

Step 1: Define the evaluation criteria and choose websites for evaluation. The evaluation criteria are based on the E-S-QUAL model and the chosen websites include three Greek coffee-chain B2C e-commerce websites.

Step 2: Construct a suitable instrument and collect experts' opinions. An online questionnaire is created, and experts accept to take part in the investigation, completing pairwise comparisons matrices among all dimensions and sub-dimensions, using the ratings: $1=$ Equally preferred, $2=$ Equally to moderately preferred, $3=$ Moderately preferred, $4=$ Moderately to strongly preferred, $5=$ Strongly preferred, $6=$ Strongly to very strongly preferred, $7=$ Very strongly preferred, $8=$ Very strongly to extremely preferred, $9=$ Extremely preferred. Their ratings represent their judgment regarding the relative importance of one dimension over 
another based on the goal under investigation, as well as on the relative importance of one sub-dimension over another based on the parent dimension.

Step 3: Aggregate experts' opinions. To aggregate ratings made by experts, the geometric mean is used. Let $\mathrm{M}^{\mathrm{k}}=\left(m_{i j}^{k}\right)_{n x n}$ be a pairwise comparison matrix of the $\mathrm{k}^{\text {th }}$ expert, where $\mathrm{m}_{\mathrm{ij}}$ represents the importance of dimension (or sub-dimension) i over dimension (or sub-dimension) $\mathrm{j}$. Then

$$
\mathrm{M}=\left(m_{i j}\right)_{n x m}=\left(\sqrt[n]{\prod_{k=1}^{n} m_{i j}^{k}}\right)_{n x m}
$$

Step 4: Calculate local weights. To calculate the local priority weights of dimensions and sub-dimensions we use Eq. 2.

$\mathrm{Mw}=\lambda_{\max } \mathrm{W}$

where $\lambda_{\max }$ is the maximum eigenvalue of $\mathrm{M}$ and $\mathrm{w}$ is the corresponding principal eigenvector, considered as the best estimate of the priority weights of the dimensions or sub-dimensions compared in the pairwise comparison matrix.

Step 5: Check for consistency. We compute the consistency index (CI) and consistency ratio (CR) for both dimensions and sub-dimensions, using Eq. 3 and 4.

$$
\begin{aligned}
& \mathrm{CI}=\frac{\lambda_{\max }-n}{n-1} \\
& \mathrm{CR}=\frac{C I}{R I}
\end{aligned}
$$

The random consistency index (RI) represents the consistency of a random pairwise comparison matrix. To have consistent ratings, CR value needs to be less than or equal to 0.10 .

Step 6: Calculate global weights for sub-dimensions. To calculate the global weight of the sub-dimension $\mathrm{w}_{\mathrm{j}}$ we multiply its local weight by the parent dimension's weight.

Step 7: Calculate a decision matrix. A decision matrix $D$ is calculated, where $\mathrm{d}_{\mathrm{ij}}$ represents the quality of the e-commerce website $i=1,2,3, \ldots, m$ in the sub-dimension $\mathrm{j}=1,2,3, \ldots, \mathrm{n}$.

$$
\mathrm{D}=\left[\begin{array}{cccc}
d_{11} & d_{12} & \ldots & d_{1 n} \\
d_{21} & d_{22} & \ldots & d_{2 n} \\
\ldots & & \\
d_{m 1} & d_{m 2} & \ldots & d_{m n}
\end{array}\right]
$$

Step 8: Compute the normalized decision matrix. The normalized decision matrix $R=\left(r_{i j}\right)_{n \times n}$ is computed using:

$$
\mathrm{r}_{\mathrm{ij}}=\frac{d_{i j}}{\sqrt{\sum_{i=1}^{m} d_{i j}^{2}}}
$$

Step 9: Obtain the weighted decision matrix. The weighted decision matrix V is obtained by:

$\mathrm{V}=\left(\mathrm{V}_{\mathrm{ij}}\right)_{\mathrm{mxn}}=\left(\mathrm{w}_{\mathrm{j}} \mathrm{r}_{\mathrm{ij}}\right)_{\mathrm{mxn}}$

Step 10: Determine the ideal alternative. Both the ideal $\left(\mathrm{A}^{+}\right)$and non-ideal $\left(\mathrm{A}^{-}\right)$alternatives are determined according to

$$
\begin{aligned}
& \mathrm{A}^{+}=\left\{\left(\max _{i}\left(v_{i j}\right) \text { if } j \in J\right) ;\left(\min _{i}\left(v_{i j}\right) \text { if } j \in J^{\prime}\right)\right\} \\
& \mathrm{A}^{-}=\left\{\left(\min _{i}\left(v_{i j}\right) \text { if } j \in J\right) ;\left(\max _{i}\left(v_{i j}\right) \text { if } j \in J^{\prime}\right)\right\}
\end{aligned}
$$

where $\mathrm{J}$ and $\mathrm{J}$ ' are beneficial and non-beneficial attributes, respectively.

Step 11: Calculate the distance of each alternative from the best and the worst alternative. We calculate the distance of each evaluated e-commerce website from the best and the worst website, using:

$$
\begin{gathered}
S_{i}^{+}=\sqrt{\sum_{j=1}^{n}\left(v_{i j}-v_{j}^{+}\right)^{2}}, \mathrm{i}=1,2, \ldots, \mathrm{m} \\
S_{i}^{-}=\sqrt{\sum_{j=1}^{n}\left(v_{i j}-v_{j}^{-}\right)^{2}}, \mathrm{i}=1,2, \ldots, \mathrm{m}
\end{gathered}
$$

Step 12: Rank the alternatives. We calculate the closeness coefficient $C_{i}$ using Eq. 12 to rank the evaluated e-commerce websites. The website with the higher $\mathrm{C}_{\mathrm{i}}$ is the more preferred one.

$$
C_{i}=\frac{S_{i}^{-}}{\left(S_{i}^{+}+S_{i}^{-}\right)}
$$




\section{RESULTS}

To evaluate the quality of Greek coffee-chain e-commerce websites, according to the dimensions and sub-dimensions of E-S-QUAL model, we use the 12 steps of the proposed AHP - TOPSIS methodology, discussed in the previous section. Table 2 presents the local and global weights of the sub-dimensions, along with their rankings. Each sub-dimension's local weight represents its performance in the parent dimension, whereas its global weight represents its overall performance in the E-S-QUAL model, regardless of its parent dimension. Overall CR for our data was found to be less than 0.1 , indicating the consistency of the resulting AHP model.

Table 2. Local and global weights and ranking of sub-dimensions

\begin{tabular}{llrrr}
\hline Dimensions & Sub-dimensions & \multicolumn{1}{c}{$\begin{array}{l}\text { Local } \\
\text { weight }\end{array}$} & \multicolumn{1}{c}{$\begin{array}{l}\text { Global } \\
\text { weight }\end{array}$} & Rank \\
\hline Efficiency (0.185) & SD 11 & 0.157 & 0.0290 & 13 \\
& SD $_{12}$ & 0.154 & 0.0285 & 14 \\
& $\mathrm{SD}_{13}$ & 0.145 & 0.0268 & 16 \\
& $\mathrm{SD}_{14}$ & 0.098 & 0.0181 & 19 \\
& $\mathrm{SD}_{15}$ & 0.083 & 0.0154 & 20 \\
& $\mathrm{SD}_{16}$ & 0.171 & 0.0316 & 12 \\
& $\mathrm{SD}_{17}$ & 0.079 & 0.0146 & 21 \\
& $\mathrm{SD}_{18}$ & 0.113 & 0.0209 & 17 \\
System availability (0.284) & $\mathrm{SD}_{21}$ & 0.160 & 0.0454 & 8 \\
& $\mathrm{SD}_{22}$ & 0.227 & 0.0645 & 5 \\
& $\mathrm{SD}_{23}$ & 0.196 & 0.0557 & 6 \\
& $\mathrm{SD}_{24}$ & 0.418 & 0.1187 & 2 \\
& $\mathrm{SD}_{31}$ & 0.129 & 0.0359 & 10 \\
& $\mathrm{SD}_{32}$ & 0.050 & 0.0139 & 22 \\
& $\mathrm{SD}_{33}$ & 0.071 & 0.0197 & 18 \\
& $\mathrm{SD}_{34}$ & 0.293 & 0.0815 & 3 \\
& $\mathrm{SD}_{35}$ & 0.118 & 0.0328 & 11 \\
& $\mathrm{SD}_{36}$ & 0.240 & 0.0667 & 4 \\
& $\mathrm{SD}_{37}$ & 0.099 & 0.0275 & 15 \\
& $\mathrm{SD}_{41}$ & 0.171 & 0.0433 & 9 \\
& $\mathrm{SD}_{42}$ & 0.186 & 0.0471 & 7 \\
& $\mathrm{SD}_{43}$ & 0.643 & 0.1627 & 1 \\
\hline
\end{tabular}

\subsection{Local Weights of Sub-Dimensions}

Local weights of sub-dimensions under system availability - the dimension that ranks higher among all four - reveal that webpages functioning as expected, without freezing during the ordering process is the most important element. Therefore, companies that develop e-commerce websites with online ordering functionalities need to pay the necessary attention when implementing their ordering forms. Customers expect that after completing their order information on an online order form, pages will keep working, without freezing, presenting a message of either order completion or a prompt for making order changes. What customers do not expect is to come across a situation where nothing happens after they complete their order, leaving them wondering whether their order has been submitted or not. The second most important element under system availability is a website that lunches and runs immediately. Load speed is essential for the quality of a website. Many online tests offer insights and advice concerning online performance optimization. Following the page speed, the absence of crashes and the availability of the e-commerce website are prioritized. Customers would probably stop trying to make an online purchase from a website that stops working or is never available to visit.

The sub-dimension under fulfillment which obtains the higher weight is that the $\mathrm{B} 2 \mathrm{C}$ e-commerce website sends out the ordered items. That is, it is not delivering wrong or incomplete products. The second-ranked element in this category is truthfulness about products and services offered to customers. Delivery of products when promised comes next, followed by posting truthful supplies. Last in this dimension is that the website makes items available for delivery within a suitable time frame. 
The first ranked element in the privacy dimension is credit card protection. Online customers highly care about the safeguard of their sensitive personal information, giving this sub-dimension the higher score between all items in all four categories. The second-ranked item in this dimension is that the website does not share customer information with others and last comes the protection of personal information online.

The final ranked dimension is efficiency. In this dimension, simple of use comes first, having the highest local weight. Simplicity of search process and navigation follow, leaving page loading and quick access to customers at the final places.

\subsection{Global Weights of Sub-Dimensions}

Apart from the local weights, the global weights of sub-dimensions are very important, since they can provide a more complete understanding of the position of each item in relation to the overall service quality of a B2C e-commerce website. First in rankings, we find credit card information protection, followed by webpages working as expected (i.e. do not freeze) during the ordering process. Items sent as ordered come third and truthfulness about products and services follows.

\subsection{Evaluation of B2C e-Commerce Websites}

Using the results from our E-S-QUAL model with AHP methodology, we proceed in implementing TOPSIS for the evaluation of the three Greek coffee-chains B2C e-commerce websites. We first calculate the decision matrix, using expert opinions on how well each particular website (W1, W2, and W3) performs with respect to a sub-dimension, as discussed in Step 7. The results of this step are presented in Table 3.

Table 3. Decision matrix showing the evaluation made for each website with respect to each sub-dimension

\begin{tabular}{|c|c|c|c|c|c|c|c|c|c|c|c|c|c|c|c|c|c|}
\hline & $\mathrm{SD}_{11}$ & $\mathrm{SD}_{12}$ & $\mathrm{SD}_{13}$ & $\mathrm{SD}_{14}$ & $\mathrm{SD}_{15}$ & $\mathrm{SD}_{16}$ & $\mathrm{SD}_{17}$ & $\ldots$ & $\mathrm{SD}_{32}$ & $\mathrm{SD}_{33}$ & $\mathrm{SD}_{34}$ & $\mathrm{SD}_{35}$ & $\mathrm{SD}_{36}$ & $\mathrm{SD}_{37}$ & $\mathrm{SD}_{41}$ & $\mathrm{SD}_{42}$ & $\mathrm{SD}_{43}$ \\
\hline W1 & 8.08 & 7.77 & 7.55 & 7.51 & 7.54 & 7.43 & 8.24 & $\ldots$ & 7.84 & 7.53 & 8.36 & 8.25 & 7.80 & 7.83 & 8.56 & 8.77 & 8.91 \\
\hline W2 & 7.60 & 7.45 & 7.51 & 7.40 & 7.09 & 6.54 & 7.60 & $\ldots$ & 8.58 & 8.49 & 8.90 & 8.37 & 8.16 & 8.36 & 8.72 & 8.70 & 9.00 \\
\hline W3 & 7.25 & 6.95 & 6.81 & 6.67 & 7.14 & 6.63 & 7.74 & $\ldots$ & 8.62 & 8.17 & 8.25 & 8.50 & 8.51 & 8.62 & 8.34 & 8.62 & 8.72 \\
\hline
\end{tabular}

We then normalize the decision matrix, using Eq. 6. Table 4 presents the normalized decision matrix, including the experts' evaluations for each website.

Table 4. Normalized decision matrix

\begin{tabular}{|c|c|c|c|c|c|c|c|c|c|c|c|c|c|c|c|c|c|}
\hline & $\mathrm{SD}_{11}$ & $\mathrm{SD}_{12}$ & $\mathrm{SD}_{13}$ & $\mathrm{SD}_{14}$ & $\mathrm{SD}_{15}$ & $\mathrm{SD}_{16}$ & $\mathrm{SD}_{17}$ & & $\mathrm{SD}_{32}$ & $\mathrm{SD}_{33}$ & $\mathrm{SD}_{34}$ & $\mathrm{SD}_{35}$ & $\mathrm{SD}_{36}$ & $\mathrm{SD}_{37}$ & $\mathrm{SD}_{41}$ & $\mathrm{SD}_{42}$ & $\mathrm{SD}_{43}$ \\
\hline W1 & 0.61 & 0.61 & 0.60 & 0.60 & 0.60 & 0.62 & 0.61 & & 0.54 & 0.54 & 0.57 & 0.57 & 0.55 & 0.55 & 0.58 & 0.58 & 0.58 \\
\hline W2 & 0.57 & 0.58 & 0.59 & 0.59 & 0.56 & 0.55 & 0.56 & $\ldots$ & 0.59 & 0.61 & 0.60 & 0.58 & 0.58 & 0.58 & 0.59 & 0.58 & 0.59 \\
\hline W3 & 0.55 & 0.54 & 0.54 & 0.53 & 0.57 & 0.56 & 0.57 & $\cdots$ & 0.60 & 0.58 & 0.56 & 0.59 & 0.60 & 0.60 & 0.56 & 0.57 & 0.57 \\
\hline
\end{tabular}

Using Eq. 7, we then calculate the weighted normalized decision matrix, shown in Table 5.

Table 5. Weighted normalized decision matrix

\begin{tabular}{llllllllllllllll}
\hline & $\mathrm{SD}_{11}$ & $\mathrm{SD}_{12}$ & $\mathrm{SD}_{13}$ & $\mathrm{SD}_{14}$ & $\mathrm{SD}_{15}$ & $\ldots$ & $\mathrm{SD}_{32}$ & $\mathrm{SD}_{33}$ & $\mathrm{SD}_{34}$ & $\mathrm{SD}_{35}$ & $\mathrm{SD}_{36}$ & $\mathrm{SD}_{37}$ & $\mathrm{SD}_{41}$ & $\mathrm{SD}_{42}$ & $\mathrm{SD}_{43}$ \\
\hline $\mathrm{W} 1$ & 0.018 & 0.018 & 0.016 & 0.011 & 0.0090 & $\ldots$ & 0.0076 & 0.011 & 0.046 & 0.0188 & 0.037 & 0.020 & 0.025 & 0.027 & 0.094 \\
$\mathrm{~W} 2$ & 0.017 & 0.017 & 0.016 & 0.011 & 0.0085 & $\ldots$ & 0.0083 & 0.012 & 0.049 & 0.0190 & 0.039 & 0.021 & 0.025 & 0.027 & 0.095 \\
$\mathrm{~W} 3$ & 0.016 & 0.016 & 0.015 & 0.010 & 0.0085 & $\ldots$ & 0.0083 & 0.012 & 0.045 & 0.0193 & 0.040 & 0.022 & 0.024 & 0.027 & 0.092 \\
\hline
\end{tabular}

The next step is to determine the positive and the negative ideal alternatives, using Eq. 8 and 9 (Table 6), and finally to calculate the general distance from the best and the worst alternative (Eq. 10, 11) and the closeness coefficient (Eq. 12), to be able to rank the websites under evaluation. The results are presented in Table 7.

Table 6. Positive ideal solution and negative ideal solution

\begin{tabular}{|c|c|c|c|c|c|c|c|c|c|c|c|c|c|c|c|c|}
\hline & $\mathrm{SD}_{11}$ & $\mathrm{SD}_{12}$ & $\mathrm{SD}_{13}$ & $\mathrm{SD}_{14}$ & $\mathrm{SD}_{15}$ & $\mathrm{SD}_{16}$ & $\ldots$ & $\mathrm{SD}_{32}$ & $\mathrm{SD}_{33}$ & $\mathrm{SD}_{34}$ & $\mathrm{SD}_{35}$ & $\mathrm{SD}_{36}$ & $\mathrm{SD}_{37}$ & $\mathrm{SD}_{41}$ & $\mathrm{SD}_{42}$ & $\mathrm{SD}_{43}$ \\
\hline $\mathrm{A}^{-}$ & 0.016 & 0.016 & 0.015 & 10 & 008 & .018 & & 0.008 & .011 & 0.04 & 0.019 & 0.03 & 0.020 & 0.024 & 0.027 & 0.092 \\
\hline $\mathrm{A}^{+}$ & 0.018 & 0.018 & 0.016 & 0.011 & 0.009 & 0.020 & ; & 0.008 & 0.012 & 0.049 & 0.019 & 0.040 & 0.022 & 0.025 & 0.027 & 0.095 \\
\hline
\end{tabular}


As Table 7 suggests, the best-ranked website is W2, followed closely by W1. Website W3 comes last in rankings.

Table 7. General distance, closeness coefficient, and ranking of websites

\begin{tabular}{ccccc}
\hline & $\mathrm{S}^{+}$ & $\mathrm{S}^{-}$ & $\mathrm{C}_{\mathrm{i}}$ & Ranking \\
\hline $\mathrm{W} 1$ & 0.0061 & 0.0070 & 0.5377 & 2 \\
\hline $\mathrm{W} 2$ & 0.0056 & 0.0068 & 0.5489 & 1 \\
$\mathrm{~W} 3$ & 0.0077 & 0.0050 & 0.3930 & 3 \\
\hline
\end{tabular}

Consequently, B2C e-commerce website 2, scoring the highest rank in electronic service quality, can be considered as the benchmarking coffee-chain e-shop for the improvement of the service quality of the other websites in the same field.

\section{CONCLUSIONS}

In this study, we use the E-S-QUAL model and AHP methodology to weight the elements that affect electronic service quality and then we rank three coffee-chains' $\mathrm{B} 2 \mathrm{C}$ e-commerce websites using the results of the AHP and TOPSIS. Our methodology consists of 12 steps. We first defined the evaluation criteria and chose the websites under evaluation. In our study, the evaluation criteria consisted of the dimensions and sub-dimensions of the E-S-QUEL model. We then constructed an online questionnaire and collected experts' opinions who made pair-wise comparisons on the model's evaluated criteria. Using their answers, we aggregated their opinions and calculated local weights for each dimension and sub-dimension. We checked for consistency using consistency index (CI) and consistency ratio (CR) and we moved on to calculating the global weights for the sub-dimensions. The next step was to apply TOPSIS to construct a decision matrix, which was normalized and weighted using the results from AHP. Finally, we calculated the distance of each alternative from the best and the worst alternative, to rank the coffee-chains e-shops.

Our results indicate that the most important dimension in evaluating B2C e-commerce websites is system availability, which measures the functionality of the website from a technical point of view. Fulfillment comes next, which controls the extent to which promises about item availability and order delivery is fulfilled. Privacy, which inspects the degree to which a website safeguards customer information comes third, leaving efficiency that refers to the easiness of accessing and using a website at the final place.

Website designers can benefit from our study since they can focus on the most important elements when developing an e-commerce website. Security of credit card information, webpages that do not freeze during the ordering process, a website that launches immediately and does not crush are four of the most important evaluation sub-dimensions a developer should consider.

Our study also has managerial implications, since companies offering their products and services online can control the performance of their e-commerce websites, considering the ranking of the E-S-QUAL model's dimensions and sub-dimensions. Apart from making checks for their existing website to see if it meets the requirements and to demand alterations, companies should also control whether other important factors, like items sent to customers as ordered and truthfulness about their products and services, are fulfilled. In nowadays changing and demanding environment, business survival is more crucial than ever before. The exploitation of our study's results could offer companies the opportunity to make improvements that matter to their online customers and witness an increase in sales during the pandemic.

Our proposed methodology is not limited to the scope of our research. It can also be applied for the evaluation of websites from different sectors and even for the evaluation of other areas, apart from B2C e-commerce websites, where pairwise comparisons are important in providing improvements to service operations. 


\section{REFERENCES}

Ahmed, R. R., Romeika, G., Kauliene, R., Streimikis, J. \& Dapkus, R. 2020. ES-QUAL model and customer satisfaction in online banking: evidence from multivariate analysis techniques. Oeconomia Copernicana, 11, 59-93.

Arcand, M., Promtep, S., Brun, I. \& Rajaobelina, L. 2017. Mobile banking service quality and customer relationships. International Journal of Bank Marketing.

Contactpigeon. 2020. How has COVID-19 Impacted Ecommerce Trends? [Online]. Available: https://blog.contactpigeon.com/covid-19-ecommerce-impact/ [Accessed 23/10/2020].

Dalbehera, S. 2020. Measuring Service Quality in Digital Library Services by the Research Scholars of SOA University of Odisha Using ES-QUAL Model. International Perspectives on Improving Student Engagement: Advances in Library Practices in Higher Education. Emerald Publishing Limited.

Eltrun, R. I. O. R. C. G. A. 2020. Greek Consumers Significantly Increase Use of E-commerce [Online]. Available: https://greece.greekreporter.com/2020/04/07/greek-consumers-significantly-increase-use-of-e-commerce-surveyshows/ [Accessed 23/10/2020].

Foodservice. 2019. Top 80 coffee bar brands in Europe [Online]. Available: https://www.food-service.de/international/intnews/ranking-top-80-coffee-bar-brands-in-europe-45918 [Accessed 26/10/2020].

Grewal, D. \& Roggeveen, A. L. 2020. Understanding retail experiences and customer journey management. Journal of Retailing, 96, 3-8.

Hanine, M., Boutkhoum, O., Tikniouine, A. \& Agouti, T. 2016. Application of an integrated multi-criteria decision making AHP-TOPSIS methodology for ETL software selection. SpringerPlus, 5, 263.

Kandulapati, S. \& Bellamkonda, R. S. 2014. E-service quality: a study of online shoppers in India. American Journal of Business.

Kang, D., Jang, W. \& Park, Y. 2016. Evaluation of e-commerce websites using fuzzy hierarchical TOPSIS based on ES-QUAL. Applied Soft Computing, 42, 53-65.

Loiacono, E. T., Watson, R. T. \& Goodhue, D. L. 2002. WebQual: A measure of website quality. Marketing theory and applications, 13, 432-438.

Masudin, I. \& Saputro, T. E. Evaluation of B2C website based on the usability factors by using fuzzy AHP \& hierarchical fuzzy TOPSIS. IOP Conference Series: Materials Science and Engineering, 2016. IOP Publishing Ltd, 012091.

Ocampo, L., Alinsub, J., Casul, R. A., Enquig, G., Luar, M., Panuncillon, N., Bongo, M. \& Ocampo, C. O. 2019. Public service quality evaluation with SERVQUAL and AHP-TOPSIS: A case of Philippine government agencies. Socio-Economic Planning Sciences, 68, 100604.

Ostovare, M. \& Shahraki, M. R. 2019. Evaluation of hotel websites using the multicriteria analysis of PROMETHEE and GAIA: Evidence from the five-star hotels of Mashhad. Tourism Management Perspectives, 30, 107-116.

Parasuraman, A., Zeithaml, V. A. \& Berry, L. L. 1988. Servqual: A multiple-item scale for measuring consumer perc. Journal of retailing, 64, 12.

Parasuraman, A., Zeithaml, V. A. \& Malhotra, A. 2005. ES-QUAL: A multiple-item scale for assessing electronic service quality. Journal of service research, 7, 213-233.

Santos, J. 2003. E-service quality: a model of virtual service quality dimensions. Managing Service Quality: An International Journal.

Santouridis, I., Trivellas, P. \& Tsimonis, G. 2012. Using ES-QUAL to measure internet service quality of e-commerce web sites in Greece. International Journal of Quality and Service Sciences, 4, 86.

Sharma, M. \& Joshi, S. 2019. Brand sustainability among young consumers: an AHP-TOPSIS approach. Young Consumers.

Soleymaninejad, M., Shadifar, M. \& Karimi, A. 2016. Evaluation of two major online travel agencies of us using TOPSIS method. Digital Technologies, 2, 1-8.

Suhartanto, D., Helmi Ali, M., Tan, K. H., Sjahroeddin, F. \& Kusdibyo, L. 2019. Loyalty toward online food delivery service: the role of e-service quality and food quality. Journal of foodservice business research, 22, 81-97.

Wirtz, J. \& Lovelock, C. 2016. Services marketing: People, technology, World Scientific Publishing Company.

Wolfinbarger, M. \& Gilly, M. C. 2003. eTailQ: dimensionalizing, measuring and predicting etail quality. Journal of retailing, 79, 183-198.

Yoo, B. \& Donthu, N. 2001. Developing a scale to measure the perceived quality of an Internet shopping site (SITEQUAL). Quarterly journal of electronic commerce, 2, 31-45.

Zaidan, A. A., Zaidan, B. B., Al-Haiqi, A., Kiah, M. L. M., Hussain, M. \& Abdulnabi, M. 2015. Evaluation and selection of open-source EMR software packages based on integrated AHP and TOPSIS. Journal of biomedical informatics, 53, 390-404.

Zeithaml, V. A., Parasuraman, A. \& Malhotra, A. 2000. A conceptual framework for understanding e-service quality: implications for future research and managerial practice, Marketing Science Institute Cambridge, MA.

Zeithaml, V. A., Parasuraman, A. \& Malhotra, A. 2002. Service quality delivery through web sites: a critical review of extant knowledge. Journal of the academy of marketing science, 30, 362-375. 